\title{
PENINGKATAN DAN PENERAPAN SMK3L PADA PEMBANGUNAN PJU TENAGA SURYA DI WONOSOBO
}

\author{
Bagus Wahyu Utomo \\ Sekolah Tinggi Teknologi Adisutjipto \\ Jl. Janti Blok. R, Lanud Adisutjipto, Bantul, Daerah Istimewa Yogyakarta, Indonesia \\ Email: baguswahyu@stta.ac.id
}

\begin{abstract}
ABSTRAK
Penerapan pada budaya K3L merupakan bagian integral pembangunan nasional untuk meningkatkan daya saing dan prduktivitas Indonesia. Berdasarkan data Badan Penyelenggara Jaminan Sosial (BPJS) Ketenagakerjaan, sepanjang tahun 2017, tercatat 1.877 klaim atau setara dengan nilai $R p$ 41,2 miliar. Pekerjaan konstruksi dianggap memiliki resiko tinggi terhadap angka kecelakaan kerja. Data kecelakaan kerja menyebutkan bahwa $30 \%$ kasus kecelakaan kerja terjadi pada sektor konstruksi.

Para pekerja konstruksi pembangunan PJU Solar Cell di daerah Wonosobo belum mengetahui mengenai sistem manajemen keselamatan, kesehatan kerja dan lingkungan. Sehingga, jika tempat kerja tersebut sehat dan aman, maka setiap orang dapat dengan mudah melakukan pekerjaannya secara efektif dan efisien. Namun sebaliknya, jika tempat kerja tersebut kurang teroganisir dengan baik dan masih banyak terdapat potensi bahaya, potensi kerusakan dan banyaknya absen karena sakit oleh karyawan, dapat mengakibatkan hilangnya pendapatan untuk karyawan dan produktifitasnya akan berkurang bagi perusahaan.

Penyuluhan/sosialisasi ini termasuk berhasil walaupun mengalami beberapa kendala saat pelaksanaan. Masyarakat yang bekerja sewaktu musim proyek seperti ini memiliki pengetahuan akan hak dan kewajibannya terkait dengan K3. Sehingga para pekerja dapat lebih memahami resiko yang mungkin saat bekerja.
\end{abstract}

Kata kunci: Pekerjaan Konstruksi, Penerangan Jalan Umum, SMK3L

\begin{abstract}
The application of HSE culture is an integral part of national development to increase Indonesia's productivity and competitiveness. Based on data from the Manpower Social Security Organizing Agency (BPJS), throughout 2017, 1,877 claims were recorded, equivalent to $R p 41.2$ billion. Construction work is considered to have a high risk of work accident rates. Occupational accident data states that $30 \%$ of work accident cases occur in the construction sector.

The PJU Solar Cell construction workers in the Wonosobo area do not yet know about the safety, occupational health and environmental management system. If their workplace is safe and healthy, everyone can continue their work more effective and efficient. Conversely, if the workplace is not well organized and many dangers, damage and absenteeism are unavoidable, there is can make loss income for any workers and reduced productivity for their company.

This counseling / socialization is considered successful even though it has experienced several obstacles during implementation. People who work during the project season like this have knowledge of their rights and obligations related to OSH. So that workers can better understand the risks that may occur while working.
\end{abstract}




\section{PENDAHULUAN}

Proyek pembangunan PJU (Penerangan Jalan Umum) tenaga surya adalah upaya konservasi energi dan juga sebagai tindakan untuk mendukung pemerintah terkait kebijakan energi yang ramah lingkungan. Pembangunan PJU menggunakan tiang sebagai penyangga utama lampu dan sel surya. Tinggi tiang berkisar antara 5 hingga 12 meter, tergantung dari kapasitas sel surya dan daya lampu. Sehingga instalasi lampu dan sel surya menurut Permenaker Nomor 9 Tahun 2016 sudah termasuk dalam kategori Bekerja Pada Ketinggian.

Penerapan budaya K3L merupakan bagian dari pembangunan nasional untuk meningkatkan daya saing dan produktivitas di Indonesia. Percepatan pembangunan infrastruktur yang dilakukan pemerintah, menelan banyak korban kecelakaan. Berdasarkan data dari (BPJS) Badan Penyelenggara Jaminan Sosial - Ketenagakerjaan, sepanjang tahun 2017, terdapat 1.877 klaim atau setara dengan nilai Rp 41,2 miliar. Kelemahan pemahaman K3 di kalangan pekerja konstruksi perlu mendapat perhatian. Kelalaian yang terjadi kerap menyebabkan kecelakaan kerja.

Proses konstruksi di Indonesia masih sering mengabaikan masalah keselamatan, kesehatan kerja dan lingkungan (K3L). Peningkatan jumlah hamir dua kali lipat terhadap jumlah tenaga kerja konstruksi pada tahun 2010 sebanyak 4.844 .689 orang menjadi 8.208.086 orang pada tahun 2015 (BPS, 2016). Pekerjaan konstruksi dianggap memiliki resiko tinggi terhadap angka kecelakaan kerja. Data kecelakaan kerja menyebutkan bahwa kasus kecelakaan kerja terjadi di sektor konstruksi dengan jumlah sekitar 30\% (Pritanti dkk, 2012).

\section{TINJAUAN PUSTAKA}

Menurut ILO (2013), Potensi bahaya listrik yang dapat menimpa pekerja konstruksi adalah medan listrik, bahaya kejut dari aliran listrik, dan panas yang ditimbulkan dari energi listrik. Pekerja dapat mengalami potensi bahaya listrik pada kondisi-kondisi sebagai berikut:

- Rangakaian listrik bertegangan tinggi disentuh atau berhubungan dengan pekerja

- Konduktor (grounding) dan konduktor yang tidak ditanahkan (grounding) menjadi area kerja karyawan.

- Pekerja bekerja pada bagian konduktor yang ditanahkan dengan material yang tidak ditanahkan.

- Area diantara konduktor yang ditanahkan dan yang tidak ditanahkan menjadi area kerja karyawan.

Dampak cidera yang terjadi akibat dari bahaya arus kejut pada pekerja konstruksi, tergantung pada:

a) Bagian tubuh yang tersentuh.

b) Besar dan kecil nya arus yang mengalir pada tubuh pekerja.

c) Durasi saat pekerja terkena arus kejut tesebut.

Besar dan kecilnya arus yang mengalir ini tergantung besar beda resistansi dan potensial. Dampak signifikan dari arus kejut pada manusia dapat mengakibatkan hingga kematian. 
Potensi bahaya bekerja pada ketinggian pekerja konstruksi adalah dari manusia, lingkungan, peralatan, prosedur dan organisasi. Pekerja dapat mengalami bahaya bekerja di ketinggian pada kondisi-kondisi sebagai berikut:

- Lingkungan: Pada kondisi cuaca, kondisi jenis pekerjaan sering berpindah-pindah, kondisi permukaan yang licin dan kondisi lingkungan yang berserakan serta tidak bersih, serta kondisi pelengkapan dan peralatan mekanik yang kurang memadai.

- Prosedur: kesalahan penggunaan alat dan tidak ada penilaian resiko

- Manusia: Kurangnya Pengetahuan, kurangnya keahlian dan keterbatasan kemampuan, kondisi tidak fit saat bekerja, lelah dan lesu, sering menggunakan jalan pintas, dan berperilaku yang tidak aman.

- Peralatan: Peralatan pencegah dan penahan jatuh tidak terstandar.

Dampak cidera yang diakibatkan oleh jatuh dari atas ketinggian sebuah bangunan atau tertimpa material dari atas ketinggian adalah patahnya tulang kaki dan pergelangan kaki, patah tulang tengkorak, dan patah tulang persendian punggung (Melvin, 2015).

Oleh karenanya kita perlu melihat penyebab dan dampak yang ditimbulkannya. Dalam penerapan manajemen risiko K3L ada beberapa tahapan yang perlu dilakukan, diantaranya adalah menentukan konteks, melakukan identifikasi risiko, melakukan penilaian risiko, lemakukan analisis risiko, dan melakukna mitigasi risiko (Hakim, 2017).

Dari hal tersebut, maka persoalan yang dihadapi oleh mitra kami dalam hal ini adalah sebagai berikut:

1) Bagaimana mendefinisikan potensi bahaya yang akan muncul dan resikonya di lokasi kerja.

2) Bagaimana menghilangkan potensi bahaya tersebut dan resikonya di lokasi kerja.

3) Bagaimana membuat laporan $\mathrm{K} 3$ di lokasi kerja.

4) Bagaimana penggunaan tools $\mathrm{K} 3$

\section{METODOLOGI PENELITIAN}

Tahap awal dari kegiatan ini merupakan perencanaan kegiatan yang akan dilakukan kedepan nya. Proses perencanaan ini meliputi identifikasi pada kebutuhan, dilanjutkan dengan identifikasi pada potensi dan kelemahan yang ada dari kegiatan ini, menentukan jalan keluar dan kegiatan yang akan dilakukan, dan membuat pengorganisasian kegiatan. Perencanaan disusun dan disesuaikan dengan kegiatan masyarakat.

Tahap kedua merupakan pelaksanaan dari kegiatan yang telah direncanakan sebelumnya. Kegiatan tahap kedua dilaksanakan secara serentak oleh masyarakat sesuaikan dengan yang telah direncanakan.

Pada tahap ketiga atau terakhir, akan dilakukan monitoring dan evaluasi terhadap kegiatan yang telah berlangsung. Kegiatan ini dilakukan secara serentak dengan masyarakat.

Dalam penerapan manajemen risiko K3L (Kesehatan, Keselamatan Kerja dan Lingkungan), ada beberapa tahap yang perlu dilakukan diantaranya adalah menentukan konteks permasalahan, melakukan identifikasi resiko yang muncul, penilaian terhadap resiko tesebut, analisis resiko, dan terakhir adalah mitigasi risiko. 
Penyuluhan Pengetahuan Keselamatan dan Kesehatan Kerja (K3) Umum untuk Karyawan Penerangan Jalan Umum Tenaga Surya (PJU TS) PT. Surya Energi Indotama dilakukan di Kecamatan Wonosobo Jawa, Kabupaten Wonosobo, Jawa Tengah. . Karyawan ini direkrut dari masyarakat sekitar yang memiliki Pendidikan maksimal SMA.

Karyawan yang berasal dari masyarakat sekitar memiliki pendidikan maksimal SMA sehingga belum secara aktif memahami praktek K3 dan penggunaan APD melakukan kegiatan pekerjaannya. Hal ini dikarenakan batas waktu perekrutan dan pelatihan yang cukup singkat dari PT. Surya Energi Indotama. Berdasarkan keadaan tersebut, maka perlu diadakan sosialisasi dan edukasi yang akan membuat karyawan dapat aktif dan memahami K3 dan kewajiban penggunaan APD saat bekerja.

\section{HASIL DAN PEMBAHASAN}

Pelaksanaan pengabdian masyarakat dibagi menjadi 3 hari disesuaikan dengan permasalahannya:

\subsection{Hasil}

1) Pengenalan pengetahuan $\mathrm{K} 3$ dan Alat Pelindung Diri (APD)

Hari, tanggal : Jumat, 26 Juli 2019

Lokasi : Kabupaten Wonosobo

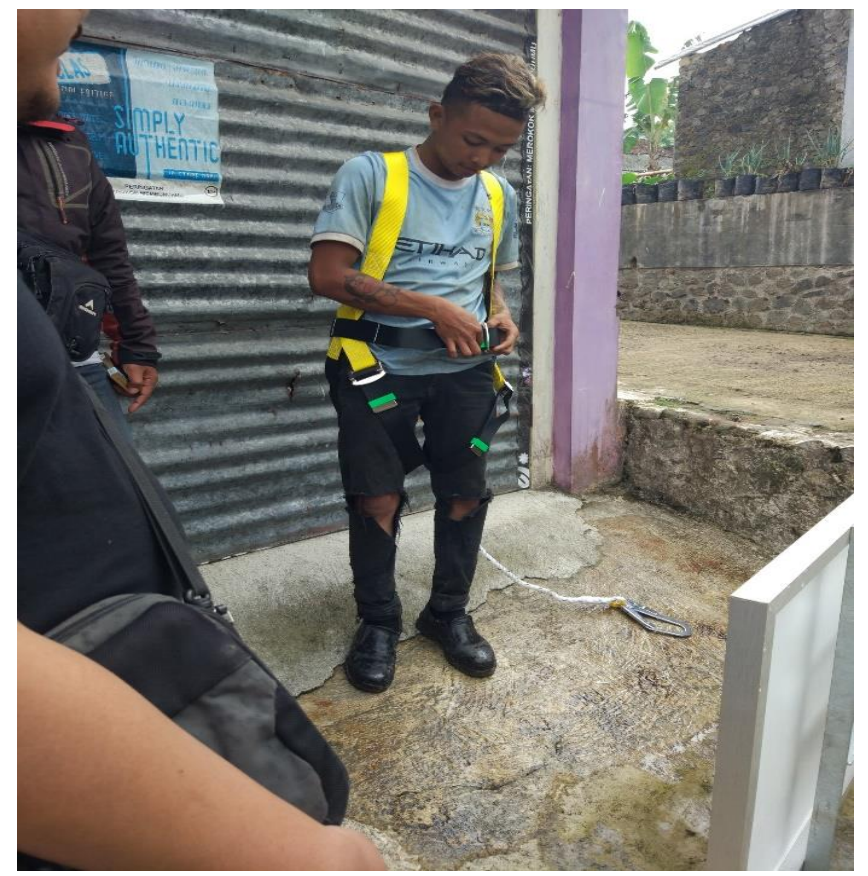

Gambar 1. Pengenalan APD

2) Sosialisasi dampak positif sadar K3 dan penggunaan APD

Hari, tanggal : Sabtu, 27 Juli 2019

Lokasi : Kabupaten Wonosobo 


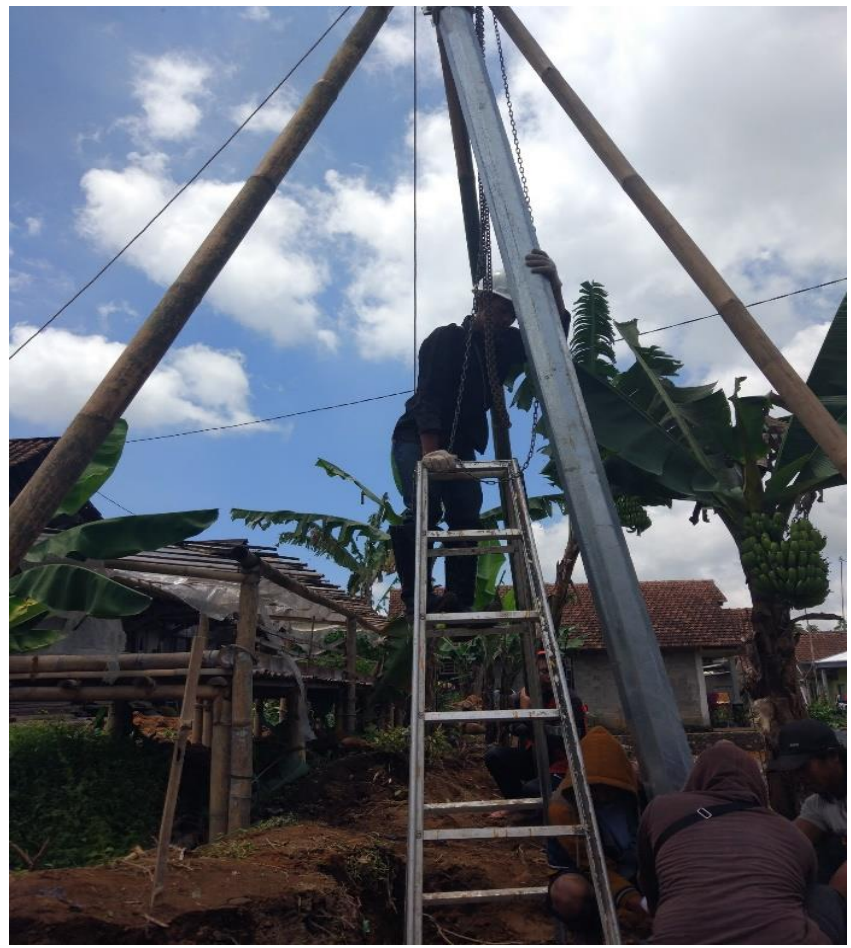

Gambar 2. Sosialisasi Penggunaan APD

3) Sosialisasi akan pentingnya menjadi karyawan yang selalu sadar mengenai K3 dan penggunaan APD (self awareness)

Hari, tanggal : Minggu, 28 Juli 2019

Lokasi

: Kabupaten Wonosobo

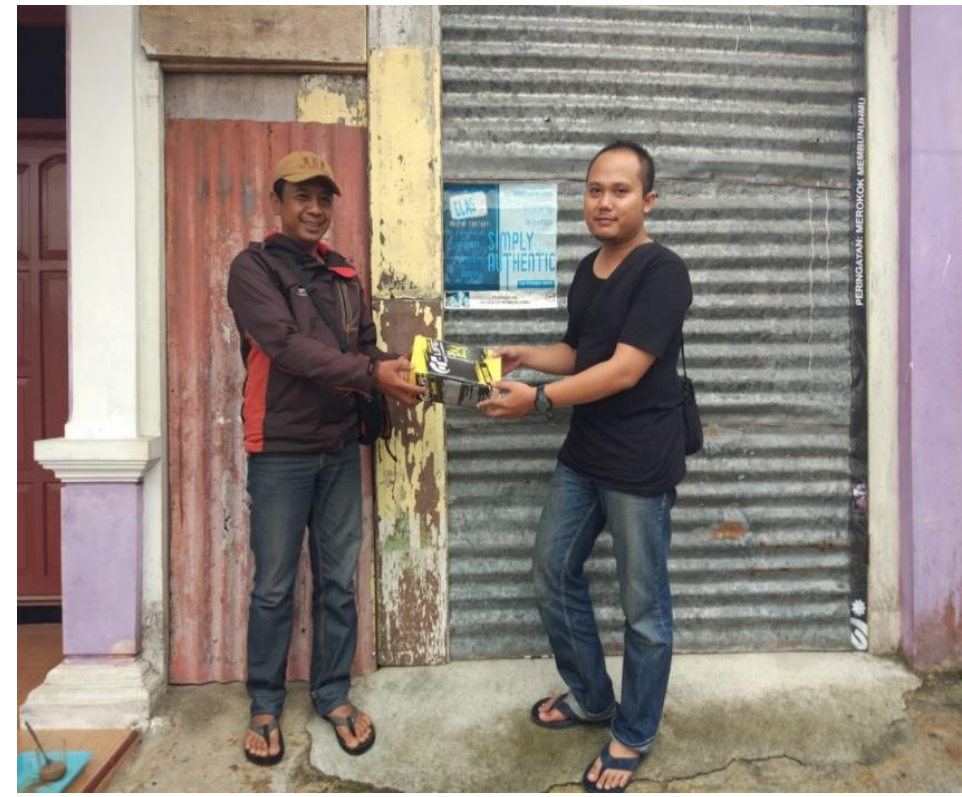

Gambar 3. Serah Terima APD

\subsection{Kendala}

Beberapa kendala saat pelaksanaan:

1) Adanya deadline pekerjaan menyebabkan penyesuaian strategi sosialisasi K3. 
2) Sosialisasi dilakukan ditengah-tengah pekerjaan sekaligus mengkoreksi kesalahan yang ada dari pekerja yang kaitannya dengan K3.

3) APD dari kantor tidak mencukupi/belum datang, sehingga penyuluh harus memberikan (menyumbang) peralatan $\mathrm{K} 3$ untuk menunjang sosialisasi.

\subsection{Pembahasan}

Penyuluhan/sosialisasi ini termasuk berhasil walaupun mengalami beberapa kendala saat pelaksanaan. Masyarakat yang bekerja sewaktu musim proyek seperti ini memiliki pengetahuan akan hak dan kewajibannya terkait dengan K3. Sehingga para pekerja dapat lebih memahami resiko yang mungkin saat bekerja.

Beberapa saran terhadap pelaksanaan kegiatan pengabdian masyarakat dari kendala yang kami hadapi adalah:

1) Perlu dilakukan penjadwalan dengan seluruh pihak yang terlibat dalam kegiatan pengabdian masyarakat.

2) Sosialisasi dapat dilakukan ketika sebelum para peserta bekerja, saat istirahat siang, atau setelah pekerjaan peserta selesai.

3) Mempersiapkan segala kebutuhan terkait kegiatan sejak dari jauh-jauh hari agar pelaksanaan kegiatan tidak terganggu.

\section{DAFTAR PUSTAKA}

Hakim, A. R. Implementasi Manajemen Risiko Sistem Kesehatan, Keselamatan Kerja dan Lingkungan (K3L) pada Pembangunan Flyover Pegangsaan 2 Kelapa Gading Jakarta Utara. MEDIA KOMUNIKASI TEKNIK SIPIL, 23(2), 113-123.

ILO. (2013). Keselamatan dan Kesehatan Kerja di Tempat Kerja: Sarana untuk Produktivitas. International Labour Office. Jakarta.

Melvin, J. W., \& Yoganandan, N. (2015). Biomechanics of brain injury: a historical perspective. In Accidental Injury (pp. 221-245). Springer, New York, NY.

Pritanti, H., \& Purwoto, S. (2012). Pertanggungjawaban Pidana Terhadap Kontraktor Dalam Hal Terjadi Kecelakaan Kerja Menurut Undang-Undang Nomor 3 Tahun 1992 Tentang Jaminan Sosial Tenaga Kerja. Diponegoro Law Journal, 1(4). 